\title{
Market Orientation and Organizational Performance of Small and Medium Enterprises in Puttalam District
}

\author{
W.A.P. Pramodanie ${ }^{1}$, D.M.T.D. Dissanayake ${ }^{2}$ \& S.M.N. Praveeni ${ }^{3}$ \\ 1,2,3 Department of Business Management \\ Faculty of Business Studies \& Finance \\ Wayamba University of Sri Lanka \\ Kuliyapitiya \\ SRI LANKA \\ tanya@wyb.ac.lk ${ }^{2}$, praveeni@wyb.ac. $\mathrm{lk}^{3}$
}

\begin{abstract}
The aim of the study was to investigate the relationship of Marketing Orientation on Organizational Performance of Small and Medium Enterprises (SMEs) in Puttalam District. On one hand, the study identifies the components of market orientation related with Business performance and on the other hand the significant association between Market Orientation and SMEs' Business Performance. The study focused on three (3) dimensions related to market orientation and one dimension related to business performance. The selected sample for the study contained 110 owners from 110 SMEs in Puttalam district using convenient sampling method. The level of measuring variables was interval and the relevant statistical techniques for these measures were correlation and regression analyses. Data analysis was conducted by using Statistical Package for Social Sciences (SPSS). Four hypotheses were tested to assess the empirical relationships among variables. Looking at the overall association among the variables it was observed that there is a high positive correlation between the market orientation and business performance $(r=0.931)$. Subsequently, factors such as customer orientation, competitor orientation and inter-functional coordination were found to be significantly impact on business performance of SMEs. Finally, these findings may lead to making some recommendations to improve the current level of market orientation factors of owners in SMEs which might lead to an increase in their business performance. Therefore, this study attempts to bring a validated framework to inform a suitable market orientation factors for the SMEs.
\end{abstract}

Keywords: Business Performance, Market Orientation, SMEs

\section{INTRODUCTION}

Market orientation has become a center of attention of many authors for over 30 years (Parasuraman, 1983; Whyte, 1985; Greenley, Matcham, 1986; Naidu and Narayana, 1991). The importance of market orientation in affecting businesses profitability is well documented in marketing literature (Narver \& Slater, 1990; Ruekert, 1992; Ngai \& Ellis, 1998). These works span from both developed (Harris, 2000; Perry \& Shao, 2002; Elg, 2003; Green Jr. et al., 2005; Keskin, 2006; Sen, 2006; Ozer et al., 2006) and developing (Agarwal et al., 2003; Kuada \& Buatsi, 2005; Dwairi et al., 2007) economies. The central argument of 
the developed and developing countries' studies demonstrates the indispensable role that market orientation plays in an organization's marketing activities in achieving superior performance in its chosen markets.

In Sri Lanka SMEs plays a major role in economic growth. SMEs have been recognized as an important strategic sector in Sri Lanka for generating high economic growth, reducing unemployment, inequality and poverty (Ministry of Enterprise Development, 2002). Sri Lanka's economy is predominantly a Small and Medium Enterprise economy where over $50 \%$ of GDP is produced by the SME sector. SMEs are found in all sub-sectors of the economy, with a large concentration in manufacturing, and a further concentration of the small ones with $5-10$ workers. They are widely spread across urban, rural and estate sectors (International Labour Organization, 2002).

However, there is lack of enough empirical and conceptual studies of market orientation and business performance among SMEs in Sri Lankan Context specially in Puttalam District. Puttalam District is clearly a gateway to profitable investment, Because of attractive natural environment, climate, agriculture and plantation. Tourism attractiveness increased the no. of SMEs in North Western province. As well as the agriculture playing a crucial role in the development of the central region of Sri Lanka and presenting exciting opportunities for the entrepreneurs. This research attempts to measure the marketing knowledge in SME and its relationship with the business performance. So, it's expected to explore the relationship of marketing orientation and improvement needs for future marketing success.

The aim of this paper is to examine and evaluate the degree of marketing orientation in businesses from SMEs in Puttalam District and to identify impact of marketing orientation on business performance.

\section{LITERATURE REVIEW}

Throughout the marketing literature, the adoption of the marketing concept is seen to be a foundation for successful performance. The marketing concept was formally introduced in the writings of McKitterick (1957), Felton (1959), and Keith (1960). It defines a distinct organizational culture that puts the customer in the center of the firm's thinking about strategy and operations (Deshpande, Farley and Frederick, 1993; Deshpande and Webster 1989). It can also be viewed as a philosophy of doing business or as a culture that permeates every aspect of an organization's operation (Houston, 1986; Wong and Saunders, 1993; Hunt and Morgan, 1995).

There has been increased interest in the market orientation construct in the past two decades. Following this development, many attempts have been made by researchers to appreciate its make-up resulting in the operationalization of its definition as a construct (Blankson et al., 2006). Most definitions developed were derived from the conceptualization of both Kohli and Jaworski (1990) or Narver and Slater (1990). According 
to Kohli and Jaworski (1990), while the marketing concept is commonly defined as a philosophy or way of thinking that guides the allocation of resources and the formulation of strategies for an organization, market orientation is considered to be the activities involved in implementation of the marketing concept.

From the strategic marketing literature, market orientation involves the use of superior organizational skills in understanding and satisfying customers (Day, 1990). In essence, market orientation is derived from the application of marketing concept and it requires firms to monitor rapidly changing customer needs and wants, determine the impact of these changes on customer satisfaction, increase the rate of product innovation, and implement strategies that build the firms' competitive advantages.

Although performance can have a variety of meanings (short-term or long-term, financial or organizational benefits), it is broadly viewed from two perspectives in the previous literature. First, there is the subjective concept, which is primarily concerned with performance of firms relative to that of their competitors (Golden, 1992). The second method is the objective concept, which is based on absolute measures of performance (Chakravarthy, 1986; Cronin and Page, 1988). For this study, a subjective rather than an objective approach was used for the following two reasons. First, company information is usually classified as highly confidential. Respondents may be reluctant to provide hard financial data. Second, past studies have reported a strong association between objective measures and subjective responses (Dawes, 1999; Jaworski and Kohli, 1993; Pearce, Robbins and Robinson, 1987; Robinson and Pearce, 1988; Venkatraman and Ramanujam, 1986). During the decade of the 1990s, a steady stream of research has focused on the impact of market orientation upon business performance. Indeed, market orientation has long been associated with higher result in terms of business profitability (Narver \& Slater, 1990) as well as success in the market place (Jaworski \& Kohli, 1993). Other studies have shown that marketoriented organizations are likely to experience improved levels of employee satisfaction, esprit de corps and organizational commitment (Ruekert, 1992; Jaworski \& Kohli, 1993).

However, mixed findings were found. Deng and Dart (1994), reported a positive link between market orientation and performance, while Diamantopoulos and Hart (1993) identified a weak association between market orientation and performance, and Bhuian (1997) found no link between market orientation and performance for Saudi Arabian banks.

Given the contradictory findings among the previous literature, many researchers have echoed the call for a need to assess the hypothesized impact of market orientation on business performance (Appiah-Adu, 1997; Bhuian,1997; Kohli et al., 1993). In this study, the market orientation of SMEs in Sri Lanka is examined. 


\section{METHODS}

The study applied the quantitative design utilizing the questionnaire for data collection.

\subsection{Conceptual Framework}

Following figure 1 illustrates the conceptual framework of the study.

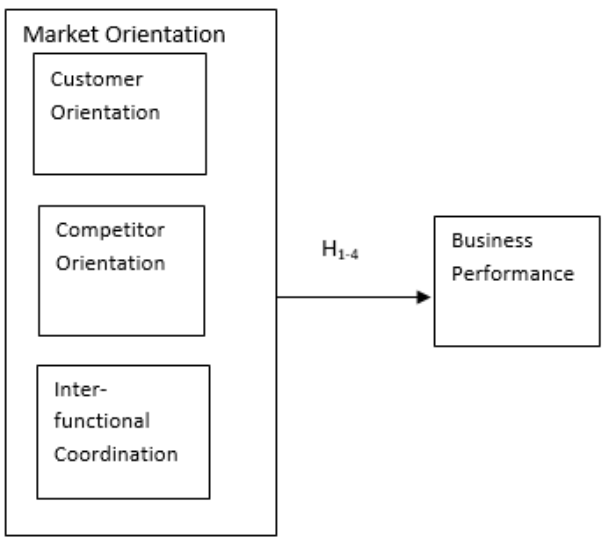

Figure 1. Conceptual Framework

\subsection{Hypotheses}

$\mathrm{H}_{1}$ : Customer $\quad$ Orientation significantly relates with Business Performance

$\mathrm{H}_{2}$ : Competitor Orientation significantly relates with Business Performance

$\mathrm{H}_{3}$ : Inter functional Coordination significantly relates with Business Performance

$\mathrm{H}_{4}$ : Market Orientation significantly impact on Business Performance

\subsection{Population and Sampling}

The study targeted a population of owners of all the SMEs in Puttalam District.

According to Creswell (2009); Creswell and Plano Clark (2017) followed by the cross-sectional survey, distribution of the questionnaire was conducted and yielded 110 responses from the potential respondents. According to Green (1991), the minimum sample size for a population of $107(\mathrm{n}$ $\geq 50+(8 * m))$. Thereby, the sample obtained within this study was an adequate representation of the total population.

\subsection{Measurements of Research Constructs}

The market orientation construct was measured by the market orientation scale developed by Narver and Slater (1990). The instrument consisted of three subscales used to measure customer orientation, competitor orientation and inter-functional coordination. This instrument has received widespread support in the literature for its reliability and validity (Chan and Ellis, 1998; Greenley, 1995; Slater and Narver, 1994; Van Egeren and O'Connor, 1988). To measure market orientation with Narver and Slater's scale, a 5-point scoring format $(1=$ strongly disagree; $5=$ strongly agree) was employed for all 13 items.

To measure business performance, each respondent in this study was asked to evaluate his/her company's current business performance relative 
to its major competitors with respect to the following four items: (1) sales growth, (2) customer retention, (3) ROI, and (4) market share. Responses were made on a 5-point scale ranging from "Strongly Agree", to "Strongly Disagree'.

\section{Methods of Data Collection}

Questionnaires were an efficient data collection mechanism when the researcher knew exactly what is required and how to measure the variables of interest. Questionnaires can be administered personal, mailed to the respondents or electronically distributed (Sekaran, 2006). This study is made use of a closed-ended questionnaire to collect data from selected owners of SMEs who are from Puttalam District.

The resulting data obtained from the respondents were entered into SPSS software version 21 and Correlation and regression analysis were used.

\section{RESULTS}

\subsection{Respondent Profile}

The profile of the respondents and their companies is shown in Table 1.

\section{Table1. Respondent Profile} Analysis

\begin{tabular}{|c|c|c|}
\hline Profile & Frequency & Percentage \\
\hline \multicolumn{3}{|c|}{ Gender } \\
\hline Male & 58 & $57 \%$ \\
\hline Female & 42 & $43 \%$ \\
\hline \multicolumn{3}{|c|}{ Age } \\
\hline $17-21$ & 13 & $12 \%$ \\
\hline $22-26$ & 26 & $24 \%$ \\
\hline $27-30$ & 20 & $18 \%$ \\
\hline $31-35$ & 33 & $30 \%$ \\
\hline $36-50$ & 13 & $12 \%$ \\
\hline$>50$ & 5 & $5 \%$ \\
\hline
\end{tabular}

\begin{tabular}{lcc}
\multicolumn{2}{c}{ Form of Enterprise } \\
$\begin{array}{l}\text { Sole proprietorship } \\
\text { Partnership }\end{array}$ & 61 \\
Private Limited & 39 & $55 \%$ \\
\multicolumn{1}{c}{ Category of the Firm } \\
Mobile/Carts & $35 \%$ \\
Computers & $10 \%$ \\
FastFood/Rest & $8 \%$ \\
Xeg.Elowers deli & $12 \%$ \\
Book/Stationary & $18 \%$ \\
Grocery/Stores & $24 \%$ \\
Car/Bike repair & $15 \%$ \\
Electronic/Homeapp & $10 \%$ \\
Other & $8 \%$ \\
& & $9 \%$ \\
& $6 \%$
\end{tabular}

Source Survey 2018

\subsection{Construct Validity and Reliability}

In determining the internal consistency of constructs in the model, Cronbach's alpha and KMO and Bartlett's test were used in line with recommendations from Hair et al. (2017) and Kline (2015). Table 2 shows the results on the internal consistency measures of the reflective model.

Table 2. Validity and Reliability Analysis

\begin{tabular}{|c|c|c|c|}
\hline Constructs & $\begin{array}{l}\text { Cronbac } \\
\text { h Alpha }\end{array}$ & $\begin{array}{l}\text { KMO } \\
\text { value }\end{array}$ & $\begin{array}{l}\text { Bartlett's } \\
\text { Test }\end{array}$ \\
\hline $\begin{array}{l}\text { Customer } \\
\text { Orientation }\end{array}$ & 0.803 & 0.848 & .000 \\
\hline $\begin{array}{l}\text { Competitor } \\
\text { Orientation }\end{array}$ & 0.703 & 0.834 & .000 \\
\hline $\begin{array}{l}\text { Inter } \\
\text { functional } \\
\text { Coordination }\end{array}$ & 0.747 & 0.827 & .000 \\
\hline $\begin{array}{l}\text { Business } \\
\text { Performance }\end{array}$ & 0.947 & 0.831 & .000 \\
\hline \multicolumn{4}{|c|}{ Source Survey 2018} \\
\hline $\begin{array}{l}\text { The values } \\
\text { for the refle } \\
\text { model achi } \\
\text { as the val }\end{array}$ & $\begin{array}{l}\text { tained } \mathrm{f} \\
\text { ve mod } \\
\text { ed relia } \\
\text { of } \mathrm{Cr}\end{array}$ & $\begin{array}{l}\text { om C } \\
\text { shov }\end{array}$ & $\begin{array}{l}\text { nbach's } \\
\text { that the } \\
\text { tandards } \\
\text { Alpha }\end{array}$ \\
\hline
\end{tabular}


greater than 0.7 is considered reliable (Nunnally, 1978). According to the factor analysis results (Table 2), values for the KMO test were above 0.5 and all the values for Bartlett's test indicated below 0.05 which is confirmed the validity requirements of the data set. The KMO test was used to verify the sampling adequacy for the analysis.

\subsection{Correlation Analysis}

Correlations between the constructs are as follows. The objective of the correlation analysis is to measure the degree to which two constructs are related.

Table 3. Correlations Analysis

\begin{tabular}{|c|c|c|c|}
\hline Relationship & $\begin{array}{c}\text { P- } \\
\text { Value }\end{array}$ & $\begin{array}{l}\text { Pearson } \\
\text { Correlation }\end{array}$ & Correlation \\
\hline $\begin{array}{l}\text { Customer } \\
\text { Orientation } \\
\text { and Business } \\
\text { Performance }\end{array}$ & 0.00 & .915 & $\begin{array}{l}\text { High } \\
\text { positive }\end{array}$ \\
\hline $\begin{array}{l}\text { Competitor } \\
\text { Orientation } \\
\text { and Business } \\
\text { Performance }\end{array}$ & 0.00 & .835 & $\begin{array}{l}\text { High } \\
\text { positive }\end{array}$ \\
\hline $\begin{array}{l}\text { Inter } \\
\text { functional } \\
\text { Coordination } \\
\text { and Business } \\
\text { Performance }\end{array}$ & 0.00 & .904 & $\begin{array}{l}\text { High } \\
\text { positive }\end{array}$ \\
\hline $\begin{array}{l}\text { Market } \\
\text { Orientation } \\
\text { and Business } \\
\text { Performance }\end{array}$ & 0.00 & .931 & $\begin{array}{l}\text { High } \\
\text { positive }\end{array}$ \\
\hline
\end{tabular}

Results reported in Table 3 show that correlations among the three components of market orientation and Business Performance which is ranged from .835 to .931 , and all correlations were statistically significant at $p<.05$. Each of the components were highly correlated (.8 and above) with the Business Performance.

Hypothesis were tested based on the Pearson Correlation coefficient(r) and table 3 shows the results relating to different relationships between constructs. Accordingly, all the four hypotheses are accepted.

\subsection{Regression Analysis}

Further, researcher conducted a regression analysis to identify the overall impact level of Market Orientation on the Business Performance. The $\mathrm{R}^{2}$ indicates that $86.7 \%$ of the variation in Business Performance is significantly explained by variation in overall Market Orientation. $\mathrm{R}$ square indicates that there was somewhat high degree of fit with the regression model. The $F$ value is $700.992(p=0.000)$ that is significant at 0.000 , which suggest that the Market Orientation has significantly explained of the variation in the Business Performance. As indicated by table 4, considering to this results Market orientation had strong significant $(\mathrm{p}=0.000)$ and positive impact on the business performance with a standardized Beta of 0.931 .

Table 4. Regression Analysis

\begin{tabular}{lcll}
\hline Relationship & $\begin{array}{c}\text { P- } \\
\text { Value }\end{array}$ & $\begin{array}{l}\text { Standard } \\
\text { Coefficient }\end{array}$ & Results \\
\hline $\begin{array}{l}\text { Market Orientation } \\
\text { and Business }\end{array}$ & 0.00 & .931 & $\begin{array}{l}\text { High } \\
\text { positive }\end{array}$ \\
Performance & & & \\
& & & \\
\hline Source Survey 2018 & & &
\end{tabular}




\section{DISCUSSION AND CONCLUSION}

On the basis of results obtained by evaluation of the conducted research on the sample of companies engaged are confirmed the existence of relationship between marketing orientation and performance of company. Existence of this relationship is proven decades by results of various international researches implemented in different countries around the world, on companies of different sizes operating in different sectors of economy. These researches are mainly focused on examination of relationship of marketing orientation and performance of companies. Methodology of the research is mainly based on the methodology of original authors, while we deliver new perspective due to chosen sample of companies and a new country context. The high positive relationship of marketing orientation with business performance indicators were confirmed. This result is consistent with some pervious research (Peters and Austin, 1985; Peters and Waterman, 1982). In specific terms, the results suggest that the existence of strong customer focus leads to an even greater relationship between and performance of sampled SMEs $(\mathrm{r}=0.915)$. Similarly, stronger market turbulence in the SMEs sector generates stronger relationship between market orientation and performance of SMEs $(r=0.931)$.

Therefor any business viability in the long run certainly requires a responsive approach to customer changes in terms of their preferences in consumption and also competition that emerged in the market place by competitors. For small or even micro firms it is crucial to increase its market orientation by engaging in developing capabilities which could effectively be used to satisfy the ever-changing customer wants and needs. To create superior value for customers, the business must create value for itself. For this, not only leadership but all employees in the small sector must play a significant role to promote the market orientation behavior throughout the firm.

Policy makers should consider organizing seasonal courses and training to owners and manager of small businesses on the use of marketing strategies in gaining competitive advantage. The owner/manager's attitude is the key driving force to support and appreciate this behavior, not only for a greater level of market orientation but also support innovative strategies that the firm can adopt to respond to the changing customers' behavior as well as stand a head against their competitors. Market orientation has positive influence on the overall performance in SMEs, it is certainly interesting to note that in this study, SMEs are rather driven by competitor orientation than the customer orientation, this indicates that small firms are certainly constantly seeking information about their close competitors to ensure that what exactly their competitors are doing so they can make their strategies accordingly to outperform them.

It is also demonstrating that if Puttalam district SMEs are successful 
in business performance, marketing orientation should be followed, further studies should be carried out on marketing capabilities of these small business in the Puttalam district in order to find marketing inabilities and educate management of these firms on how to be market oriented in the particular industry.

This study investigating the relationship between market orientation and business performance of SMEs in Sri Lanka with special references to Puttalam District. In overall, these firms should attempt to follow market orientation to increase their business performance.

\section{REFERENCES}

Agarwal, S., Erramilli, M.K. and Dev, C.S., 2003. Market orientation and performance in service firms: role of innovation. Journal of services marketing.

Appiah-Adu, K., 1997. Marketing in emerging countries: evidence from a liberalized economy. Marketing Intelligence \& Planning.

Bhuian, S.N., 1997. Exploring market orientation in banks: an empirical examination in Saudi Arabia. Journal of Services Marketing.

Blankson, C., Motwani, J.G. and Levenburg, N.M., 2006. Understanding the patterns of market orientation among small businesses. Marketing Intelligence \& Planning.
Chakravarthy, B.S., 1986. Measuring strategic performance. Strategic management journal, 7(5), pp.437-458.

Creswell, J.W. and Clark, V.L.P., 2017. Designing and conducting mixed methods research. Sage publications.

Creswell, J.W., 2009. Mapping the field of mixed methods research.

Cronin, J.J. and Page, T.J., 1988. An examination of the relative impact of growth strategies on profit performance. European Journal of Marketing.

Dawes, J., 1999. The relationship between subjective and objective company performance measures in market orientation research: further empirical evidence. Marketing bulletindepartment of marketing massey university, 10, pp.65-75.

Day, R.H. and Huang, W., 1990. Bulls, bears and market sheep. Journal of Economic Behavior \& Organization, 14(3), pp.299-329.

Deng, S. and Dart, J., 1994. Measuring market orientation: a multi-factor, multi-item approach. Journal of marketing management, 10(8), pp.725-742.

Deshpande, R. and Webster Jr, F.E., 1989. Organizational culture and marketing: defining the research agenda. Journal marketing, 53(1), pp.3-15.

Deshpandé, R., Farley, J.U. and Webster Jr, F.E., 1993. Corporate culture, customer orientation, and 
innovativeness in Japanese firms: a quadrad analysis. Journal of marketing, 57(1), pp.23-37.

Diamantopoulos, A. and Hart, S., 1993. Linking market orientation and company performance: preliminary evidence on Kohli and Jaworski's framework. Journal of strategic marketing, 1(2), pp.93-121.

Dwairi, M., Bhuian, S.N. and Jurkus, A., 2007. Revisiting the pioneering market orientation model in an emerging economy. European Journal of Marketing.

Elg, U., 2003. Retail market orientation: a preliminary framework. International Journal of Retail \& Distribution Management.

Felton, A.P., 1959. Making the marketing concept work. Harvard business review, 37, pp.55-65.

Golden, B.R., 1992. The past is the past-or is it? The use of retrospective accounts as indicators of past strategy. Academy of Management journal, 35(4), pp.848-860.

Green Jr, P.E., 2005. Fiber to the home: The new empowerment (Vol. 4). John Wiley \& Sons.

Green, S.B., 1991. How many subjects does it take to do a regression analysis. Multivariate behavioral research, 26(3), pp.499-510.
Greenley, G.E., 1995. Forms of market orientation in UK companies. Journal of Management Studies, 32(1), pp.47-66.

Harris, P.L., 2000. The work of the imagination.

Blackwell Publishing.

Houston, F.S., 1986. The marketing concept: what it is and what it is not. Journal of marketing, 50(2), pp.81-87.

Hunt, S.D. and Morgan, R.M., 1995. The comparative advantage theory of competition. Journal of marketing, 59(2), pp.1-15.

Jaworski, B.J. and Kohli, A.K., 1993. Market orientation: antecedents and consequences. Journal of marketing, 57(3), pp.53-70.

Keith, R.J., 1960. The marketing revolution. Journal of marketing, 24(3), pp.35-38.

Keskin, H., 2006. Market orientation, learning orientation, and innovation capabilities in SMEs. European Journal of innovation management.

Kline, R.B., 2015. Principles and practice of structural equation modeling. Guilford publications.

Kohli, A.K. and Jaworski, B.J., 1990. Market orientation: the construct, research propositions, and managerial implications. Journal of marketing, 54(2), pp.1-18.

Kuada, J. and Buatsi, S.N., 2005. Market orientation and management practices in 
Ghanaian firms: revisiting the Jaworski and Kohli framework. Journal of International Marketing, 13(1), pp.58-88.

McKitterick, J., 1957. What is the marketing thought and action. American Marketing Association, Chicago, IL, pp.7182.

Naidu, G.M. and Narayana, C.L., 1991. How marketing oriented are hospitals in a declining market?. Journal of Health Care Marketing, 11(1).

Narver, J.C. and Slater, S.F., 1990. The effect of a market orientation on business profitability. Journal of marketing, 54(4), pp.20-35.

Narver, J.C. and Slater, S.F., 1990. The effect of a market orientation on business profitability. Journal of marketing, 54(4), pp.20-35.

Ngai, J.C.H. and Ellis, P., 1998. Market orientation and business performance: some evidence from Hong Kong. International marketing review.

Ngai, J.C.H. and Ellis, P., 1998. Market orientation and business performance: some evidence from Hong Kong. International marketing review.

Nunnally, J.C., 1978. Psychometric Theory 2 nd ed.

Ozer, M., 2006. New product development in Asia: An introduction to the special issue. Industrial Marketing

Management, 35(3), pp.252-261.

Parasuraman, A. and Zeren, L.M., 1983. R\&D's Relationship with Profits and Sales. Research Management, 26(1), pp.25-28.

Pearce, J.A., Robbins, D.K. and Robinson Jr, R.B., 1987. The impact of grand strategy and planning formality on financial performance. Strategic management journal, 8(2), pp.125-134.

Perry, M.L. and Shao, A.T., 2002. Market orientation and incumbent performance in dynamic market. European journal of marketing.

Peters, T.J. and Austin, N., 1985. A passion for excellence. The leadership difference.

Peters, T.J. and Waterman, R.H., 1982. In search of excellence: Lessons from America's best-run companies.

Robinson Jr, R.B. and Pearce, J.A., 1988. Planned patterns of strategic behavior and their relationship to business-unit performance. Strategic

Management Journal, 9(1), pp.43-60.

Ruekert, R.W., 1992. Developing a market orientation: an organizational strategy perspective. International journal of research in marketing, 9(3), pp.225-245. 
Ruekert, R.W., 1992. Developing a market orientation: an organizational strategy perspective. International journal of research in marketing, 9(3), pp.225-245.

Sen, S., Bhattacharya, C.B. and Korschun, D., 2006. The role of corporate social responsibility in strengthening multiple stakeholder relationships: A field experiment. Journal of the Academy of Marketing science, 34(2), pp.158-166.

Van Egeren, M. and O'Connor, S., 1998. Drivers of market orientation and performance in service firms. Journal of Services Marketing.

Venkatraman, N. and Ramanujam, V., 1986. Measurement of business performance in strategy research: A comparison of approaches. Academy of management review, 11(4), pp.801-814.
Whyte, E. G. 1985. A Multivariate Analysis of the Marketing Background and Marketing Orientation of Community Mental Health Center Chief Executive Officers and og Community Mental Health Center Marketing Programs, Dissertation, University of Mississippi. Greenley, G.E. and Matcham, A.S., 1986. Marketing orientation in the service of incoming tourism. European Journal of Marketing.

Wong, V. and Saunders, J., 1993. Business orientations and corporate success. Journal of Strategic Marketing, l(1), pp.2040. 